\title{
Photographing Mining Pollution in Gold Rush California
}

Conohar Scott

Lecturer in Photography

University of Lincoln School of Film \& Media

Brayford Pool, Lincoln, LN6 7TS

Email: cscott@lincoln.ac.uk

Tel: 07982715796

Dr. Conohar Scott is a lecturer at the University of Lincoln, UK. Conohar's research interests concern the photographic documentation of industrial pollution. As part of his research practice, Conohar founded the artist-led collective Environmental Resistance (environmentalresistance.org), which is currently comprised of specialists in photography, environmental science and graphic design. The objective of Environmental Resistance is to protest against incidents of industrial pollution in the landscape, with projects undertaken in partnership with environmental activist networks and NGOs. 


\section{Photographing Mining Pollution in Gold Rush California}

This paper draws comparison between three photographers who documented the North Bloomfield Mining Co.'s (1866-1899) hydraulic gold mine, in California. The history of the North Bloomfield Mining Co. is of interest because of the role that photography played in promoting the interests of corporate capitalism, and conversely acting as an evidential tool for farmers whose lands were flooded by polluted tailings emanating from the mine. The company twice commissioned Carleton Watkins to document their undertakings; however, this paper argues that the aesthetic of the ‘industrial sublime' originating in Watkins' photographs obfuscates an understanding of the ecological realities of mining. Alternatively, this paper presents two lesserknown photographers, J.A. Todd and 'Clinch', who adopt a counter-aesthetic approach to Watkins. Todd's photographs from the Woodruff vs. North Bloomfield [1884] trial were presented as evidence in the first collective civil action in US legal history, which pitched the interests of farmers against the corporate mining industry. The resulting Sawyer Verdict [1884] represents the USA's earliest environmental legislation, which heralded the end of the Gold Rush. The photographs of 'Clinch' were utilised in the subsequent US vs. North Bloomfield Mining Company [1899] trial, which finally put the company out of business for persistent illegalities.

Word count: 7716 


\section{Carleton Watkins' Malakoff Diggins Photographs}

In the most recent and comprehensive publication of Watkins' large-format work: Carleton Watkins: The Complete Mammoth Photographs ${ }^{1}$, Christine HultLewis describes how Carleton Watkins' career depended upon patronage from an elite coterie of capitalists who owned various mining claims in California, leading HultLewis to describe Watkins as 'one of the very first corporate photographers' (23). Hult-Lewis' description is important because it emphasises the relationship between Watkins' signature aesthetic approach to photography, which is comparable to what the contemporary photographer Edward Burtynsky describes as the 'industrial sublime $^{2}$. Commenting on Watkins' early career, Mary Warner Marien states that 'Watkins pioneered the use of photography in the courtroom' (5) because he made his name as a photographer defending the interests of his capitalist patrons in disputes over contested mining claims ${ }^{3}$. When Watkins was not involved in legal disputes, he also photographed mines in order to raise further capital investment.

Viewed from a contemporary cultural perspective, which is imbued with globalised environmental anxieties, it is important not to foster a false impression of Watkins as a cynical profiteer who photographed mining enterprises without care for the environment. Watkins' personal views on mining are not known as much of the photographer's estate was destroyed in the great San Francisco earthquake of 1906 (Hult-Lewis 3). However, it is also important to appreciate the extent to which environmental destruction was caused by the technological development of hydraulic mining, which 'completely transformed the land, killing any living thing in its path and creating new earthen forms' (Hult-Lewis 168). The technology of hydraulic mining was hugely environmentally devastating because it relied upon blasting the gold-bearing rock face with reinforced hoses called monitors. Not only did this 
reliance upon water have a tremendous impact upon surrounding ecosystems, often necessitating the redirection of entire river systems, it also created vast reservoirs of sludgy tailings which could then be treated in order to extract any gold held in suspension. Here mercury (or quicksilver) was used as a separating agent, with the result that the technology of hydraulic mining necessarily created vast reservoirs of mercury contaminated silt, which resulted in the looming threat of industrial pollution on a grand scale.

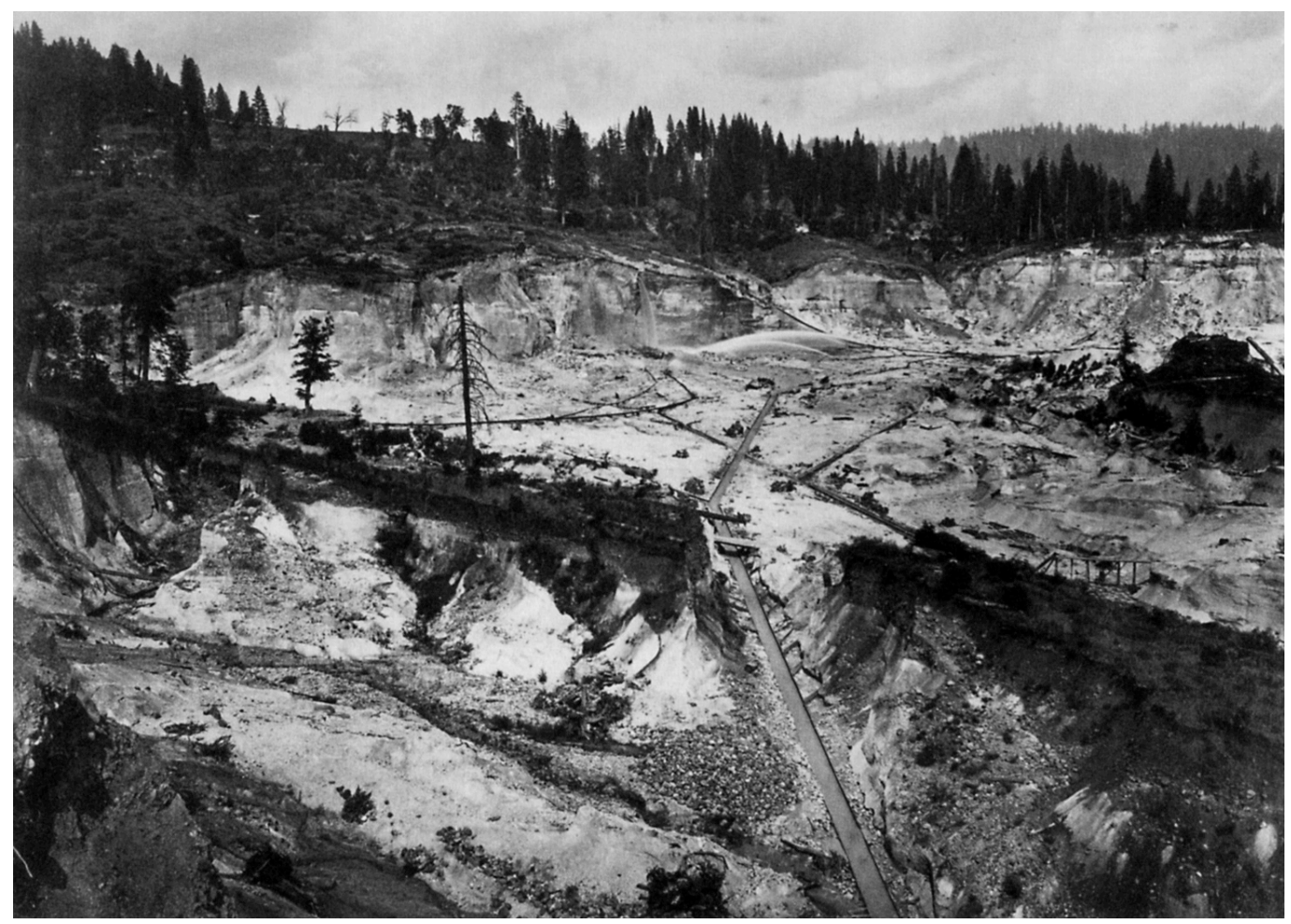

Figure 1. Watkins, Carleton. Malakoff Diggins, Looking Northeast, near North Bloomfield, Nevada County (1871). Albumen silver print. Collection of the Addison Gallery or American Art, Phillips Academy, Andover, Massachusetts.

In Watkins' photograph Malakoff Diggins, Looking Northeast, near North Bloomfield, Nevada County, (1871), see Figure 1, Watkins perches himself high on the ridge of a pit known as Malakoff Diggins. This north-eastern view of the open cast is flanked by the forest, which frames the uppermost ridge of the composition, 
except for a thin strip of land that extends into the middle of the pit from the left side of the image. Watkins utilises this dichotomy by emphasising the dynamic tension existent between the dark tones of the flora and the creamy-white highlights of exposed rock, which occupy the important middle-ground of the composition. The subjugation of the natural elements in the photograph is further accentuated by the lattice of sluice boxes and canals, which appear as violent incisions upon the topography whilst simultaneously functioning as a compositional aid, allowing the viewer to navigate through the floor of the mine towards the back-drop of the image. In the middle-ground of the photograph, a promontory of land notable for the presence of a large solitary dead tree further signifies the destruction of the forest ecosystem. What David Harvey describes as capitalism's 'ceaseless quest to dominate nature' ("The Enigma of Capital" 157) is explicit in the case of Watkins' photograph - for the engineers involved in hydraulic mining, the flora and fauna were considered as nothing more than an 'overburden', which must be swept away by the pressurised jets of water in order to reach the valuable minerals located in the bedrock below.

The subjugation of the natural world in Watkins' Malakoff Diggins photographs is further signified by the consistent use of a raised ocular perspective, which allowed potential investors the opportunity to survey the mining works from a floating bird's-eye viewpoint. This point of view, which the geographer Denis Cosgrove defines as the 'Apollonian gaze', serves to connote 'a divine and mastering view from a single perspective' (xi) which affirms the acquisitive dominance of industrial capitalism's territorial ambitions by emphasising a sense of observational privilege over the reconnoitred topography. Taken as a whole, Watkins' aesthetic approach to photographing the hydraulic mine was calculated to elicit a sense of power and awe in the minds of a contemporary audience, who might not previously 
have encountered a photographic representation of industrial transformation on such a vast scale as the Malakoff Diggins pit.

Watkins' role as a photographer documenting the North Bloomfield mining works was just one facet of a highly complex capitalist operation. What Harvey describes as a 'state-finance nexus' ("The Enigma of Capital" 48) was concomitant in order to facilitate the huge logistical and financial undertakings, which accompanied an operation of this scale. The immense need for water to power the hydraulic hoses necessitated the creation of numerous sanctioned water providers ${ }^{4}$ not to mention a host of timber companies, steam engineers, logistics operatives and additional service providers, which were required to keep the mine up and running. Such technological infrastructure at North Bloomfield also required tremendous capital outlay; the company 'absorbed some 3.5 million dollars in investments' (Hult-Lewis 154) before it produced any significant amount of gold.

The North Bloomfield Mining and Gravel Company was founded in 1866 through the incorporation of "thirty investors from San Francisco led by railroad and silver mining baron Lester Robinson, and William Ralston who founded the Bank of California' (Hoskins 17). William Ralston, his agent William Sharon, and other associates known as the 'Bank Crowd' were noteworthy figures in the Californian mining industry. As Maureen Jung observes, Ralston and his associates often lent independent mining operations capital; however, this enabled the 'Bank Crowd' to gain access to a company's accounts whereupon they 'fed rumours to the press and timed assessment calls and stock sales to drive prices up or down according to their plans' (71). Similarly, Ralston also used underhand tactics to withhold ore from smelting mills he had loaned funds to, until finally the works went out of business, 
whereupon the 'Bank Crowd' revitalised the businesses as majority shareholders (ibid.).

Ralston additionally pursued his own ambitions through investments such the North Bloomfield Mining Co. Christine Halt-Lewis records that Watkins was employed to document the North Bloomfield operation as a precursor to an international investment campaign, which was intended to secure additional funds through markets in London and Europe during the winter of 1871-2. However, the venture ran into problems, and it is not clear if any investment from Europe was ever forthcoming (Hult-Lewis 172-4). Nevertheless, it is clear that Ralston and his associates had definite ambitions to secure international funds, which would have ensured that the North Bloomfield Mining Co. was a transnational corporation with global ambitions.

In his analysis concerning the emergence of the corporation in US culture, Alan Trachtenberg observes that in the pre-Civil War era corporate status was granted solely through State legislation and was bestowed only to organisations 'serving the public good' (6) e.g. for the purposes of developing the infrastructure of the country through building transport infrastructure, or ensuring financial stability of public assets through the establishment of a State authorised insurance company. Trachtenberg goes on to explain that it was not until the "creation of national markets in the 1850s' (ibid.) that the concept of incorporation came to be redefined as an enterprise of private persons, working in pursuit of personal gain and shareholder dividends.

The shift in the social function of the corporation in the decades following on from the Civil War is indicative of the emergence of a structural flaw in capitalism, which David Harvey outlines in the Seventeen Contradictions and the End of 
Capitalism. Harvey's fourth contradiction is entitled 'Private Appropriation and Social Wealth' (53-69) and here Harvey describes how commodities are objects that represent the value of 'social labour', which can be understood as the 'common wealth' generated through the combined energies of the individuals required, in order to produce a given article. Harvey goes on to state that in capitalism:

[...] this process of private appropriation of the common wealth lies in the contradictory way in which $[\ldots]$ money represents and symbolises social labour (value). The fact that money, as opposed to the social labour it represents, is inherently appropriable by private persons means that money (provided it functions well as both a store and measure of value) can be accumulated without limit by private persons (“Seventeen Contradictions" 55).

This process is what Harvey terms as 'private appropriation' and furthermore Harvey makes clear that the private appropriation of wealth necessarily leads to a concentration of power in the hands of the few, and to the expression of greed and corruption within society.

Harvey's distinction of 'social labour' and 'private appropriation' can easily be applied to the example of William Ralston and the 'Bank Crowd'. The shift in function of the corporation in the USA, from an enterprise predicated upon generating social value to one that is invested in private appropriation, is congruent with the 'systemic banking malfeasance' (“Seventeen Contradictions” 54) which Harvey claims is a direct expression of the private accumulation of capital. What the example of the North Bloomfield Co. illustrates is that the emergence of the [mining] corporation in the USA, during the latter decades of the nineteenth century, occurred in tandem with numerous examples of financial irregularities, insider trading and 
manipulation of the stock markets, all of which prefigure much later crisis in the banking system and the economy as a whole.

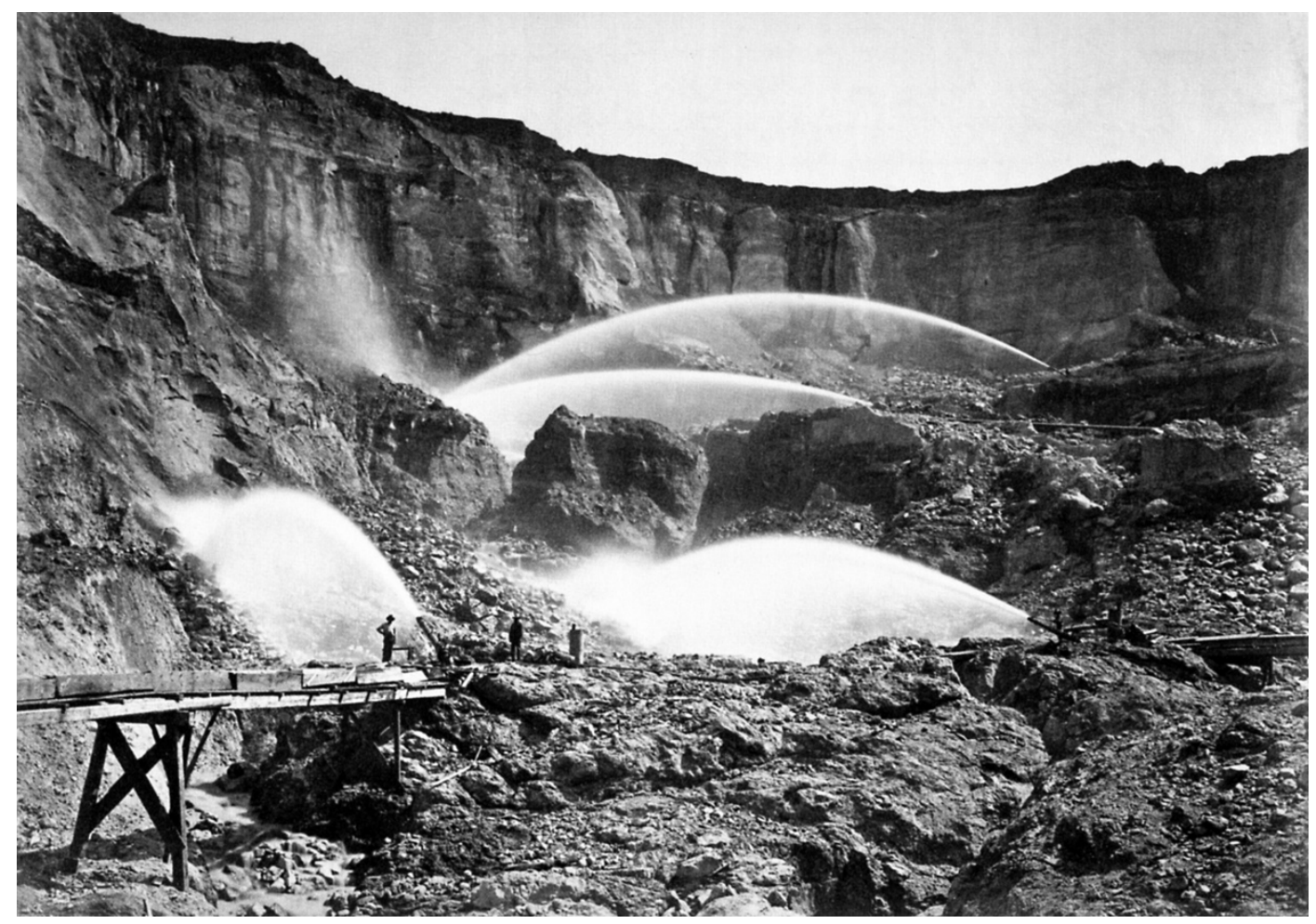

Figure 2. Watkins, Carleton. Malakoff Diggins, near North Bloomfield, Nevada County (1879-81). Albumen silver print. The Bancroft Library, University of California, Berkeley.

In her critique of Watkins' mining photographs Mary Warner Marien claims that Watkins' images use complex framing techniques, which serve to 'reconcile natural phenomena with human endeavour' (7), and are so sophisticated that 'it is difficult to think oneself outside the terms of the image to the socio-economic realities of his subject matter' (8-9) - not to mention the ecological impacts of mining. For Marien, Watkins is adept at composing images that integrate the mine into the contours of the landscape, so as to signify that the act of hydraulic mining is topographically congruent with the natural world. In Watkins' 'Malakoff Diggins, Looking Northeast, near North Bloomfield, Nevada County (1871)', Figure one, the 
horizon line populated by the arboreal forest at the top of the ridge serves to minimise the scale of ecological transformation associated with the mine by enclosing the structure with natural elements. However, in later photographs Watkins made of the Malakoff Diggins pit, such as figure two: Malakoff Diggins, near North Bloomfield, Nevada County (1879-81), any remaining vestige of the natural world recedes, or is absent totally, until the photographs increasingly take on the appearance of a lunar surface.

In Malakoff Diggins, near North Bloomfield, Nevada County (1879-81), the camera once again floats above the floor of the open cast pit; however, on this occasion the subject is the interior of the mine. In accordance with Marien's observation, Watkins' utilises the raised wooden sluices on each side of the foreground as a compositional tool, which not only leads the eye into the interior of the pit but also mimics they curvature of the horizon, creating the impression that the mine's construction is sympathetic to the surrounding topography. In the middleground, monitors shooting jets of water create soft arching highlights at odds with the violent force of the pressurised hoses. Also pictured are some miners, however, the scale of Watkins' 'industrial sublime' obfuscates any attempt to identify the labourers - they simply appear as Everyman.

In an echo of David Harvey's observations concerning the social inequalities and the concentration of power and wealth arising from 'private appropriation', Daniel Cornford describes how at the outset of the Gold Rush mining labourers lived in appalling conditions, whilst a large proportion of the workforce derived from 'Latin American peonage, North American slavery [and] Chinese indentured labor' (84). In the case of the North Bloomfield works, 'The company employed over 800 Chinese 
and 300 Whites in $1868^{\prime}$ (California State Park), which suggests that a large proportion of the miners hailed from disenfranchised, if not exploited communities. Watkins' use of the 'industrial sublime' therefore serves to obscure not only the ecological ramifications of hydraulic mining but also the social inequalities attributable to corporate mining operations such as The North Bloomfield Mining Co. This observation leads Marien to conclude that Watkins' aesthetic approach to the documentation of mining can be considered as a form of "propaganda generated as much by capitalism as by an individual' (8-9).

In Terry Eagleton's analysis of what he defines as the 'Marxist sublime' (196231), Eagleton argues that what is astonishing, terrifying or super-sensible about Marx's analysis of capital is the essential vitality of the commodity as 'an unstoppable metonymic chain in which one object refers itself to another and that to another to infinity' (213), - until finally all natural forms are transformed into commodities. For Eagleton, capital relations are indicative of a negative or a 'bad' sublime, 'along the lines of Hegel's 'bad' infinity' (ibid.), which radically alters and subverts a subjective understanding of the world: 'Like Kant's mathematical sublime, this endless accumulation of pure quantity subverts all stable representation, and money is its major signifier [...] The sublime for Marx as for Kant, is Das Unform: the formless or monstrous' (ibid.).

Applying Eagleton's concept of the 'Marxist sublime' to Watkins' photographs of the Malakoff Diggins pit, it could be argued that what is 'sublime' in Watkins' photographs is not only the physical transformation of the environment caused by hydraulic mining - stark and vast though Watkins' denuded vistas undoubtedly are but also the presence of capital as an expression of organisational and 
transformational energy, which sensibly exceeds the confines of the photographic frame. What the 'Marxist sublime' demonstrates is the organisational capacity of capitalism to redirect rivers and move mountains, to influence the polices of the State and the legislature for its own ends, to organise itself into global markets through trading on stock exchanges, to ensure that a significant proportion of the population remains disenfranchised and willing to work, in order to provide surplus value for a minority, - all of which are eventually brought to bear in the form of kinetic energy, funnelled through the circumference of a hose in order to dislodge the most totemic of all minerals - gold.

\section{J.A. Todd and the photograph as a body of Evidence}

If Watkins' Malakoff Diggins series represents the untrammelled power of capital to quite literally move mountains in the pursuit of profit, then it is logical to consider where the mercury infused sludge, which constituted the great majority of the mine's waste, ended up. Hult-Lewis comments that the dams constructed by the North Bloomfield Co. were never strong enough to contain the vast volume of sludge produced by the hydraulicing process (218). As a result, sediment cascaded onto lower ground, killing marine life and flooding the towns of Marysville and Yuba City. So severe were the floods in 1875 , that:

Over 1 billion cubic yards of debris raised the bottom parts of San Francisco Bay by as much as 3 feet. The bed of the Sacramento River rose by 16 feet, impeding navigation and causing millions of dollars in damage to California's Central Valley farms (California State Parks).

The situation in the Central Valley was clearly untenable, and it resulted in the formation of the 'Anti-Debris Association [on] August 24, 1878' (Project 
Underground) with the aim of instigating a series of lawsuits in an attempt to ban the technology of hydraulic mining in the state of California.

Throughout the 1870s the [Sacramento] Anti-Debris Association failed in their attempts to shut down the mining operations, however, their efforts were finally rewarded with the successful Edward Woodruff vs. North Bloomfield [1884] legal case. Justice Sawyer's ruling did not outlaw hydraulicing outright but placed a burden upon the North Bloomfield Co. to demonstrate that it had constructed sufficiently sturdy impounding reservoirs, which would prevent further tailings spilling into the Yuba River. The outcome of Sawyer's Verdict, which became law on the $7^{\text {th }}$ January 1884, was that hydraulic mining became less financially viable with the result that the ruling effectively ended the Gold Rush in California. The statutory limitation imposed by Sawyer was easily circumvented by mining capitalists, however, who simply relocated their hydraulic mines to other territories in the West such as Idaho, Montana and South Dakota (Isenberg 176), not mention Alaska and the Yukon in Canada, where the interests of agrarian communities downstream was not such a determining factor.

Almost certainly Edward Woodruff vs. North Bloomfield [1884] constituted 'the first major environmental decision' (Project Underground) in the legal history of the USA. The case itself was complex and long-drawn out with proceedings occurring 'over several years with 200 witnesses and 200,000 pages of testimony in all' (HultLewis 221). Given the considerable duration of the hearings, it is interesting to learn that the North Bloomfield legal team did not make use of Watkins' images. This suggests that whilst Watkins' photographs were capable of functioning as advertisements on behalf of the North Bloomfield Mining Co., the images added no 
advantage to a legal case which sought to underplay the environmental impact of hydraulicing as a mining technology.

It is important to note that the Edward Woodruff vs. North Bloomfield [1884] case was a civil action initiated by the agrarian and riparian landowners who constituted the Anti-Debris Association. The historian Andrew Isenberg notes that the plaintiff in this case, Edward Woodruff, owned '1,700 acres of wheatland near Marysville on both banks of the Yuba River' (171) and was directly affected by the flooding downstream from the North Bloomfield works. Isenberg also notes that Woodruff was:

[...] an unlikely opponent of hydraulic mining; his fortune was heavily implicated in California's urban and industrial economy. In the early $1850 \mathrm{~s}$ Woodruff made considerable profits as a landlord and real estate speculator [...] By the 1860s his investment portfolio included holdings in the Spring Valley Water Company, which provided water to hydraulic mines as well as municipalities; a copper mine in Calaveras Country; and a silver mine in Mexico. (ibid.).

Edward Woodruff therefore belonged unequivocally to the same bourgeois class as the owners of the North Bloomfield mine; as such, it would erroneous to characterise the Anti Debris Association's resistance to hydraulic mining as a revolt led by poor agrarian famers against the might of corporate capitalism. As Alan Trachtenberg explains, by the latter decades of the nineteenth century food production in many parts of the USA had become 'a capital intensive, highly mechanized industry' (23), much in the same way that mining had, and was far removed from the romantic vision of the self-sufficient small-holder who farmed to feed family first before selling any surplus on the market. 
Isenberg also describes how the Anti Debris Association was founded by 'large-scale commercial farmers $[\ldots]$ at the behest of one of the largest and most influential engines of economic development in California, the South Pacific Railroad' (166). According to Isenberg, four prominent industrialists who controlled the Southern Pacific Railroad Company - Charles Crocker, Mark Hopkins, Collis Huntington, and Leland Stanford, - had decided as far back as the 1860s that 'California's economic future was in agriculture rather than mining' (ibid.). Whilst the Anti Debris Association may well have represented the interests of small-hold farmers and homesteaders in a battle against corporate mining interests, the Association was also a means by which vying factions of capitalists attempted to seize economic advantage from the free mining companies in California, through protracted battles conducted in the judiciary.

Although the Edward Woodruff vs. North Bloomfield [1884] was a long and complex trial, it is significant that the plaintiffs utilised the power of photographic evidence by hiring a local Sacramento based photographer John A. Todd to document the extent of the debris and flooding downstream from the North Bloomfield works. As Peter Palmquist notes, J. A. Todd was a Sacramento photographer who was adept and extremely inventive at a great number of business ventures ${ }^{5}$; however, it is fair to say that Todd did not share Watkins' exemplary skill and ambition as a photographer. Nevertheless, it is important to appreciate the scope of environmental damage that Todd was engaged to document. Christine Hult-Lewis comments that after the flood of the North Bloomfield Company's English Dam in 1883, 'some 60 miles southwest of Marysville and beyond [...] orchards [were] unrecognizable as such, covered in water, silt and sand' (222). In the Sacramento Valley as a whole, Donald J. Pisani estimates that some 'thirty thousand acres of prime alluvial farmland became choked 
with mud from mining sites in the foothills' (132). It is therefore important to appreciate that what J.A. Todd was commissioned to photograph was an industrial disaster on a grand scale.

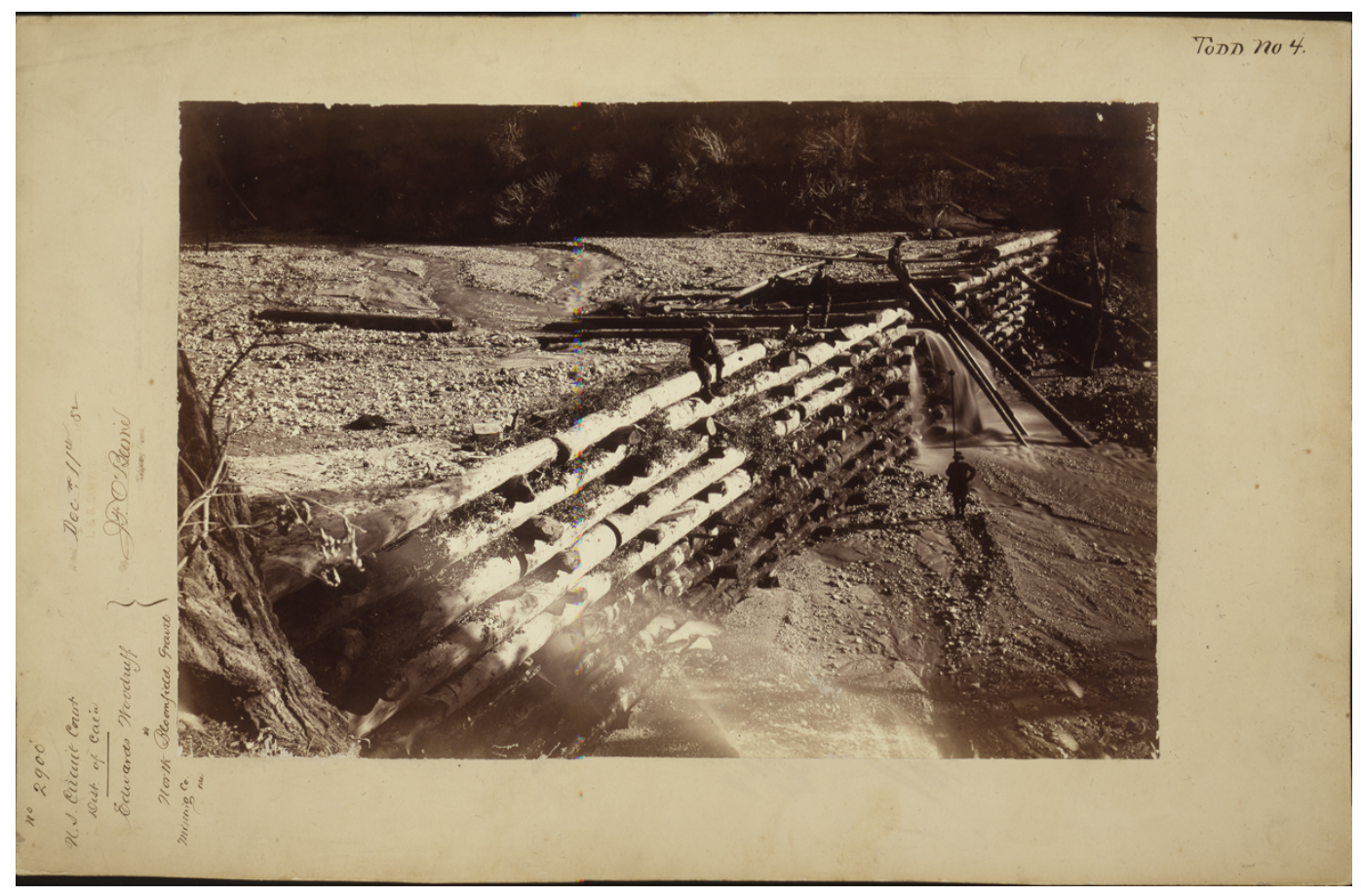

Figure 3. Todd, J.A. No. 2900 U.S. Circuit-Cal., Edward Woodruff vs. North Bloomfield Gravel Mining Co. et al., Filed Nov. 16, 1882, L.S.B. Sawyer, Clerk, by F.H. O'Beime, Deputy Clerk, Todd No. 4. Photographs of the effects of hydraulic mining. California Historical Society, San Francisco. PC-RM-OV-Todd_004.

If Watkins pioneered the use of photography as a form of 'evidence' in order to settle land-litigation disputes between rival claimants, then the photographs of J.A. Todd represent the first instance in the USA, if not the world, when photography was utilised in order to hold mining corporations to account for causing environmental pollution. In total, Todd contributed seven photographs to the legal case, from a total of seventeen, which were taken over the course of two expeditions conducted throughout a two-year period ${ }^{6}$. In his first series of prints taken late in 1882 , Todd documented various swollen and breeched dams which belonged to the North 
Bloomfield Co. Importantly, Todd's photographs enabled the Edward Woodruff legal team to establish that the North Bloomfield dams were prone to failure and insufficiently constructed.

In the photograph 'Todd No.4', Figure three, there is no indication of Watkins' raised ocular perspective which is typical of the 'industrial sublime', nor is there any evidence of Marien's observation that Watkins integrated mining structures into the surrounding topography in order to naturalise the aspect of mining. Instead, Todd presents the viewer with an unbalanced diagonal composition of the dam, which appears to uncomfortably impose the industrial artefact upon the surrounding topography. Todd's strong diagonal line of the dam wall is counterpoised only by the presence of mine employees, who provide a sense of scale by appearing astride and underneath the timber clad levee. Commenting on the failure of the dams, Raymond Dasmann notes that heavy rains contributed to the flooding of silt leaden water courses from 1862 onwards, and in 1875 the town of Marysville was all but destroyed by flooding (119). All of these events led up to the grand flood when North Bloomfield's English Dam broke in 1883. Taking all of this into consideration, it seems obvious that the miners' confidence in the integrity of their structure was somewhat misguided. Indeed, the evidential power of the image comes from the depiction of the silt, which appears to press against the wooden barrier with pregnant anticipation.

In the context of Watkin's images of the Malakoff Diggins works, Todd's photograph of the North Bloomfield levee is interesting to consider because of the limited aesthetic quality of the image. If, as Mary Warner Marien claims, Watkins' photographs are so sophisticated that it is difficult to think outside the construction of the image in order to consider the socio-economic realities of mining, then Todd's 
depiction of the dam provides a counter-aesthetic strategy, which serves to comparatively undermine Watkin's confident depictions of the mining industry. In 'Todd No.4', the composition is predicated upon the evidential function for which the photograph was intended i.e. to prove that the hydraulic mines created reservoirs of silt, which periodically broke causing nuisance to the agrarian community in the flatlands. In contrast to Watkin's vision of a brave new technological era, Todd's depiction of the North Bloomfield operation shows an industry literally creaking at the seams.

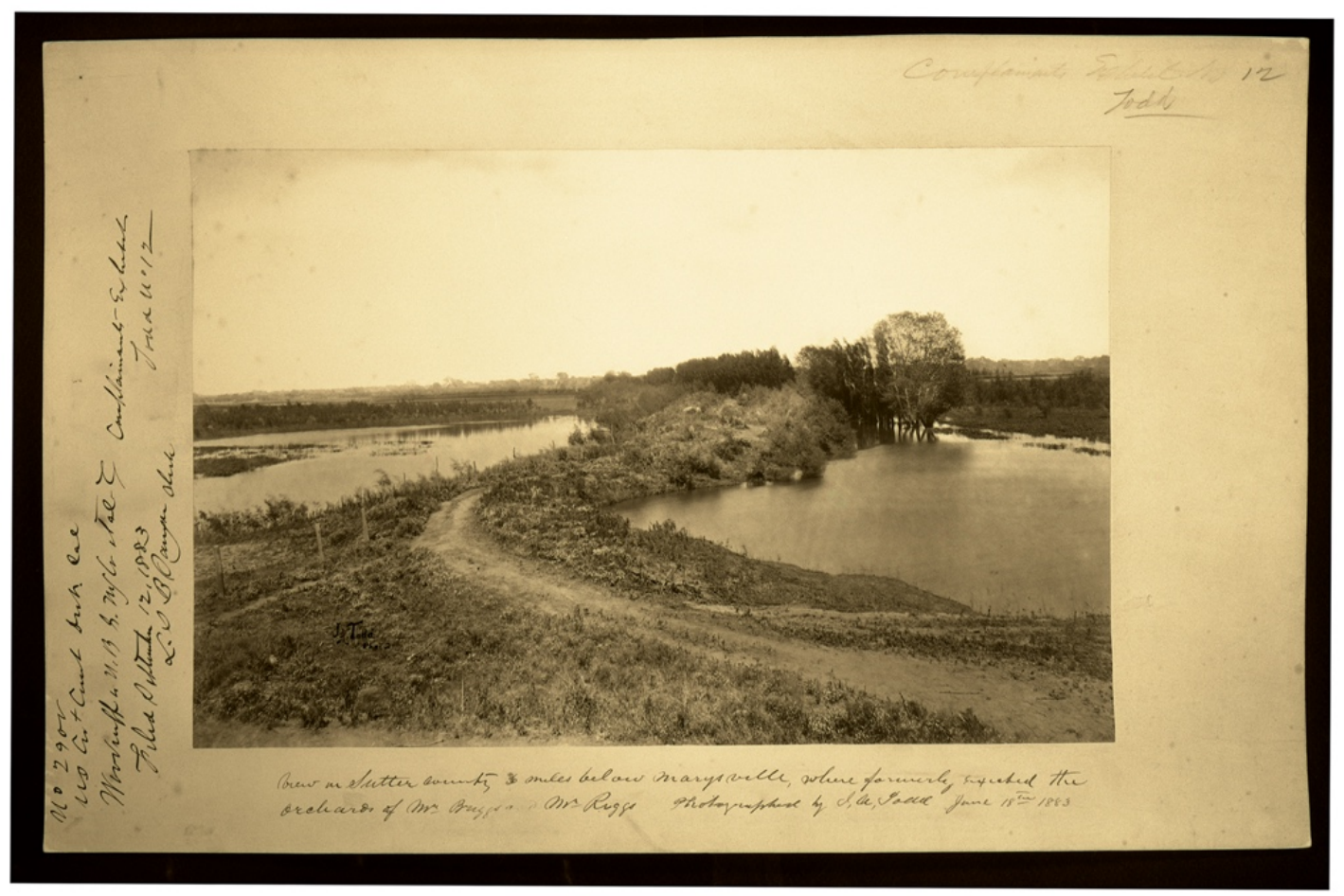

Figure 4. Todd, J.A. View in Sutter County (3)6 miles below Marysville; where formerly existed the orchards of Mr. Briggs and Mr. Riggs. Photographs of the effects of hydraulic mining. California Historical Society, San Francisco. PC-RM-OVTodd_012.

On the second expedition, which occurred after the collapse of the English Dam in the June of 1883 , Todd responded to the disaster by photographing the extent of the flooding as far afield as '60 miles southwest in Marysville and beyond' (Hult- 
Lewis 221). The resulting devastation can be observed in Figure 4, - which for the purposes of identification is titled according to the handwritten notes that appear underneath the photograph on the velum mount, and which read: 'View in Sutter County 36 miles below Marysville; where formerly existed the orchards of Mr. Briggs and Mr. Riggs (1883) ' 7 . Looking at Todd's photograph, it is easy in this instance to mistake the compositional style for that of Watkins. Not only does Todd employ the raised ocular perspective so favoured by Watkins, he also utilises the curvature of the road in order to lead the audience towards the flooded land beyond. In a great variety of Watkins' images of California the foregrounding of man-made structures such as a road represents the subjugation of the natural world, and the encroachment of civilisation on territories hitherto unsettled before the closure of the frontier. Whilst the landscape Todd had been contracted to photograph was obviously dangerous, being full of the 'slickens and quicksands' (Hult-Lewis 221), the scene he witnessed must have been one of utter devastation akin to observing the aftermath of a natural disaster. In Todd's photograph of the flooded orchards little sense of this chaos prevails. Instead, Todd forms a picturesque scene out of the disaster zone; the tall tree on the right side of the image is placed to correspond with the rule of thirds, whilst the sky glows with the warmth of sunlight creating a vista that is deceptively pastoral.

The fact that Todd, in some of his photographs, draws upon similar framing devices to Watkins in order to describe the ecological devastation caused by hydraulic mining, says much about the emergent status of photography in this early period of the medium's history. As Mary Warner Marion argues, in later decades of the nineteenth century all photographers relied upon 'aesthetic codes situated in economic necessity' (26). Photography's implicit association with capital is further emphasised by Marien when she comments that the California State Geological Surveys ${ }^{8}$ were 
not conducted solely for scientific purposes, the expeditions also provided valuable information concerning the location of mineral deposits or possible pathways for the construction of road or rail networks. This observation leads Marien to conclude that the newly emergent technology of photography worked on behalf of capital, by transforming 'nature into property' (ibid.). Taking Marien's comments into consideration, it is apparent that any instances of photography pursuing political ends which were at odds with the dominant forces of capital in this era, would be both noteworthy and exceptional.

Given photography's primary function as a tool for enabling the transformation of matter into commodities, it is nevertheless important to understand that J.A. Todd's photographs of the environmental devastation caused by hydraulicing did uniquely represent the interests of a whole spectrum of farmers and horticulturalists, - from those with modest small-holdings to established capitalists such as Edward Woodruff, - whose livelihoods were equally threatened by the propensity of the North Bloomfield dams to flood downstream. Whilst Andrew Isenberg argues that the Anti-Debris Association was influenced by a coterie of wealthy capitalists in the Southern Railroad Co., who were pursuing their own interests, it is also possible to claim that the Anti-Debris Association also represented what Robert Kelley refers to as a 'popular democracy' (115), with each member paying a small subsidy for membership which was relative to their income. Whilst it would be inaccurate to characterise the Anti-Debris Association as consisting solely of poor farmers who were confronting powerful mining capitalists, there are significant differences in how both factions relied upon a sense of community, and the immediate environment, in order to ensure a continuation of their income. 
Donald Pisani notes that 'the extent to which agriculture in the Sacramento Valley was structured by the dominance of free mining is uncertain' (143), but that wheat farming was predominant close to mining enterprises because the cultivation of cereal crops required much less care and attention, in what was a precarious environment. Interestingly, Pisani goes on to state that 'The same lack of attachment to place, the same lack of community, the same short-sightedness, and the same obsession with profit characterized both mining and agriculture, at least until horticulture gained popularity during the 1870s and 1880s' (144). In the context of J.A. Todd's View in Sutter County 36 miles below Marysville; where formerly existed the orchards of Mr. Briggs and Mr. Riggs (1883)', Pisani's comments would appear to give credence to the notion that the Anti-Debris Association did also represent the interests of people like 'Mr. Briggs and Mr. Riggs', who presumably harboured a strong attachment to the land because of the long-term commitment required to produce a successful orchard.

Justice Sawyer's closing comments in the Edward Woodruff vs. North Bloomfield [1884] trial additionally point towards the notion of the farmer/horticulturalist as a class of individual who stood in opposition to the private appropriation of corporate mining interests. Sawyer is recorded as commenting: 'It is by protecting the most humble in his small estate against the encroachments of large capital and large interests that the poor man is ultimately able to become a capitalist himself' (qtd. in Pisani 133). Whilst models of capitalist production tout court are not contested by Sawyer, his comments do draw attention to the notion that California at the time of the Edward Woodruff vs. North Bloomfield [1884] trial was a battleground for two conflicting modes of capitalist production. 
On the one hand, the hydraulic mining companies represented a heavily leveraged form of capitalism, dependent upon investment from urban centres nearby and abroad, incorporated as a result, with the overwhelming majority of investors having no direct affinity to the locality of a mine or to nearby communities. Conversely, agriculture/horticulture differed greatly with some enterprises heavily capitalised whilst others were modest family operations, tended to be dependent upon localised networks of production and distribution, and shared an obvious interest in maintaining the fertility of the soil and the vitality of nearby water courses. It is in the context of the schism between localised agrarian business on the one hand, and delocalised corporate mining enterprises on the other, that J.A. Todd's photographs must be understood.

J.A. Todd's personal views on hydraulic mining are not known. However, taking into consideration Marien's comments concerning photography's relationship to capital in this period, it is perhaps prudent to assume that Todd was a commercially motivated photographer carrying out a large local commission on behalf of his clients, which he did to the best of his abilities, irrespective of any personal views he may have held on the environmental damage caused by hydraulic mining. Moreover, whilst J.A. Todd's photographs played a modest role in what was a long drawn-out court case, from a contemporary perspective it might be argued that Todd's images are emblematic of the naïve beginnings of an environmentally conscious photographic practice, in which the technology of photography was utilised as an evidential tool, in order to hold corporate capitalist interests to account for acts of environmental degradation, which impacted adversely upon the region as a whole. 


\section{The counter-aesthetic of the 'Clinch' Photographs}

The third photographer to document the North Bloomfield Mining \& Gravel Company is not easily identified, and can only be referred to by a logo bearing the name of 'Clinch', which appears on the velum surrounding the photographs. No trace of a practitioner bearing this name can be found in Palmquist \& Kailbourn's biographical index Pioneer Photographers of the Far West. However, internet searches reveal that a photographer trading under the name of W. A. Clinch was resident at Eureka Gallery on Mill Street, Grass Valley, Nevada, during the 1890s (Auctivia). Although only a few examples of W.A. Clinch's work have been found, the photographer's practice appears to be primarily focused upon commercial portraiture through the production of cabinet cards. Whilst it is probable that this is the same 'Clinch' who documented the Malakoff Diggins site, this theory pertains to the author alone and as such remains speculative.

The eleven images attributable to 'Clinch' (NARA) pertain to court proceedings which followed the outcome of the Edward Woodruff vs. North Bloomfield [1884] trial. Dated in the NARA archives to the year 1891, the 'Clinch' photographs - see Figures five, six and seven - were submitted as part of the subsequent legal proceedings taken against the North Bloomfield Company by the Federal Government, in the years 1897-1899. This trial, known as the US vs. North Bloomfield Mining Company [1899], was once more led by US Attorney Cadwalader, who has successfully led the plaintiffs to victory in the preceding Edward Woodruff vs. North Bloomfield [1884] case.

The needs of shareholders to recoup significant amounts of investment in the North Bloomfield works ensured that in the aftermath of the Sawyer Verdict [1884] the company was reluctant to conform to the new legislation. In 1886, the North 
Bloomfield Co. was fined for operating their monitors illegally at night (California State Park) but in the aftermath of the Sawyer legislation the company remained in business by redirecting tailings to a large impounding reservoir. By the early 1890s, persistent lobbying by the mining industry's representative body, the Californian Mining Association, resulted in the passing of new legislation which was intended to help the beleaguered hydraulic mining industry. The Caminetti Act [1893] called for the establishment of a Californian Debris Association, which would conduct inspections by State registered engineers, in order to ensure that pollution of major rivers did not occur. For the mining industry, the Caminetti Act meant that mining operations could no longer be free but had to be licensed by the State. The litigation dispute, which formed the basis of the US vs. North Bloomfield Mining Company [1899] proceedings, centred upon North Bloomfield's refusal to comply with the conditions of the Caminetti Act (Knight 385-392).

Interestingly, the 'Clinch' photographs often maintain a low ocular perspective in relation to the topography of the Malakoff Diggins pit. Looking at the 'Clinch' image entered as 'Exhibit no. 6', Figure five, it is striking that very little attempt has been made by 'Clinch' to compose the photograph and delineate foreground elements using framing strategies such as repoussoir. Similarly, many of the 'Clinch' images from Malakoff Diggins do not utilise roads, bridges or sluice channels in order to guide the audience past the foreground and into the topography of the mine in a manner which might be typical of Watkins' sense of composition, or even J.A. Todd's framing of the floods in 'View in Sutter County 36 miles below Marysville; where formerly existed the orchards of Mr. Briggs and Mr. Riggs', Figure four. Instead, the photograph is devoted to documenting the loosened bedrock of the Malakoff Diggins pit, which is depicted as a chaotic sludge of rock and debris 
tumbling towards the camera. One of the most striking aspects of the image is the violence with which the uppermost ridge of the pit, and the sky above, has been cropped. Cutting in to the horizon line in such an aggressive manner suggests that 'Clinch' was committed to including as much of the hydrauliced bedrock as possible; an act which emphasises that the evidential function of the photograph superseded the photographer's aesthetic preoccupations.

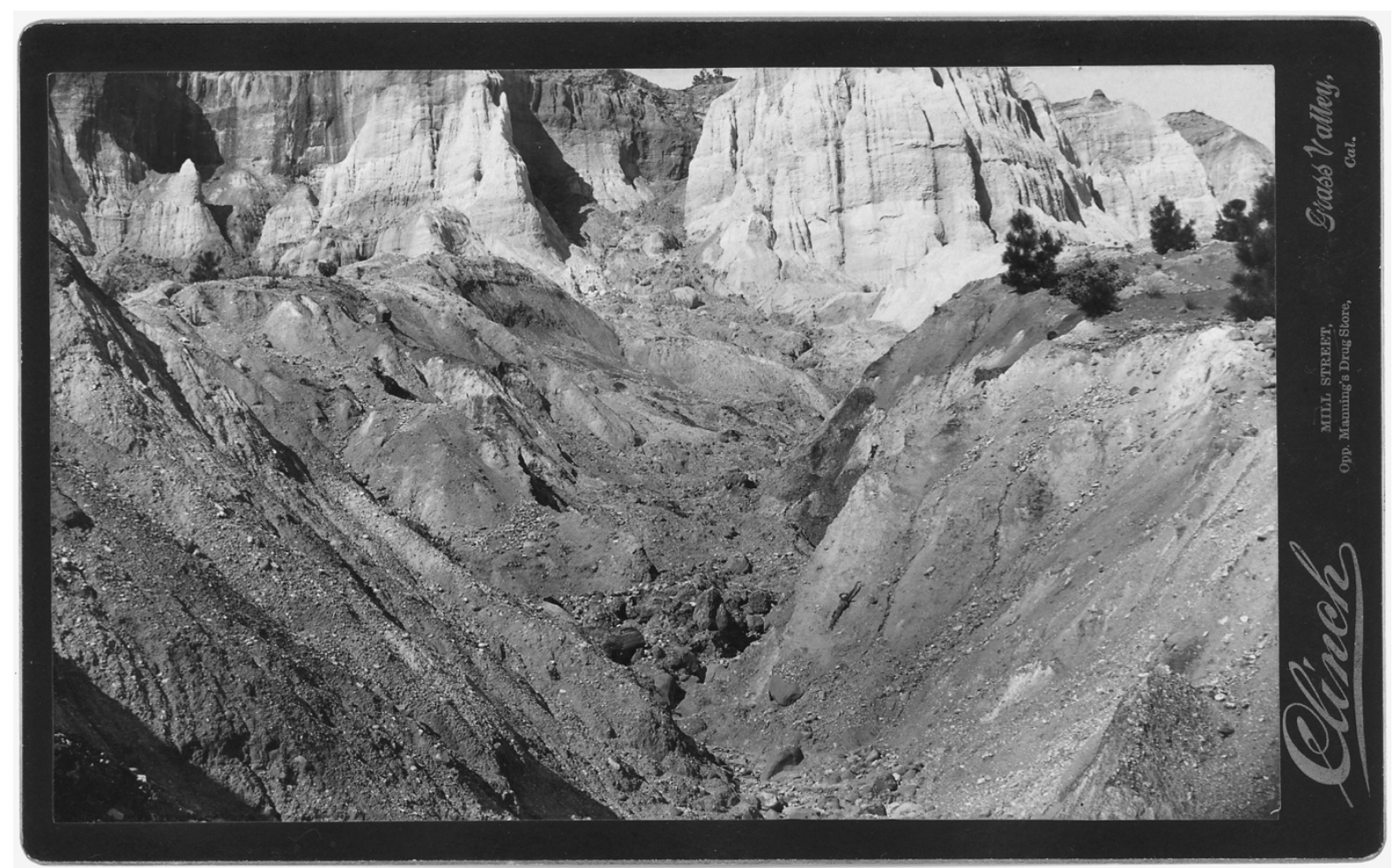

Figure 5. 'Clinch'. Respondent's Operating hydraulic mining elevator and impounding works at North Bloomfield Mine, entered as respondent's Exhibit 6, in the matter of Equity Case 7865, United States vs. North Bloomfield Gravel Mining Co. et al. US National Archives series: Civil and Appellate Case Files, compiled 1863 - 1911, NARA Identifier: 295953.

In another 'Clinch' image, which is captioned in the NARA archives as 'Exhibit 43', figure six, the photograph's primary function is to make explicit that the North Bloomfield works continued to utilise the technology of hydraulic mining long after Justice Sawyer's Verdict [1884] made the technique illegal in California. In this 
example, the photograph evidences in detail the sluice channel which feeds the monitor, and shows the floor of the pit littered with shards of wood and various other mining ephemera. Behind the muddy plume of water, which significantly does not share the sparkling highlights of Watkins' Malakoff Diggins, near North Bloomfield, Nevada County (1879-81), figure two, a rough-cut channel of tailings flows off into the distance. Overall, the photograph predominantly signifies that the act of hydraulic mining is necessarily a messy and environmentally destructive business.

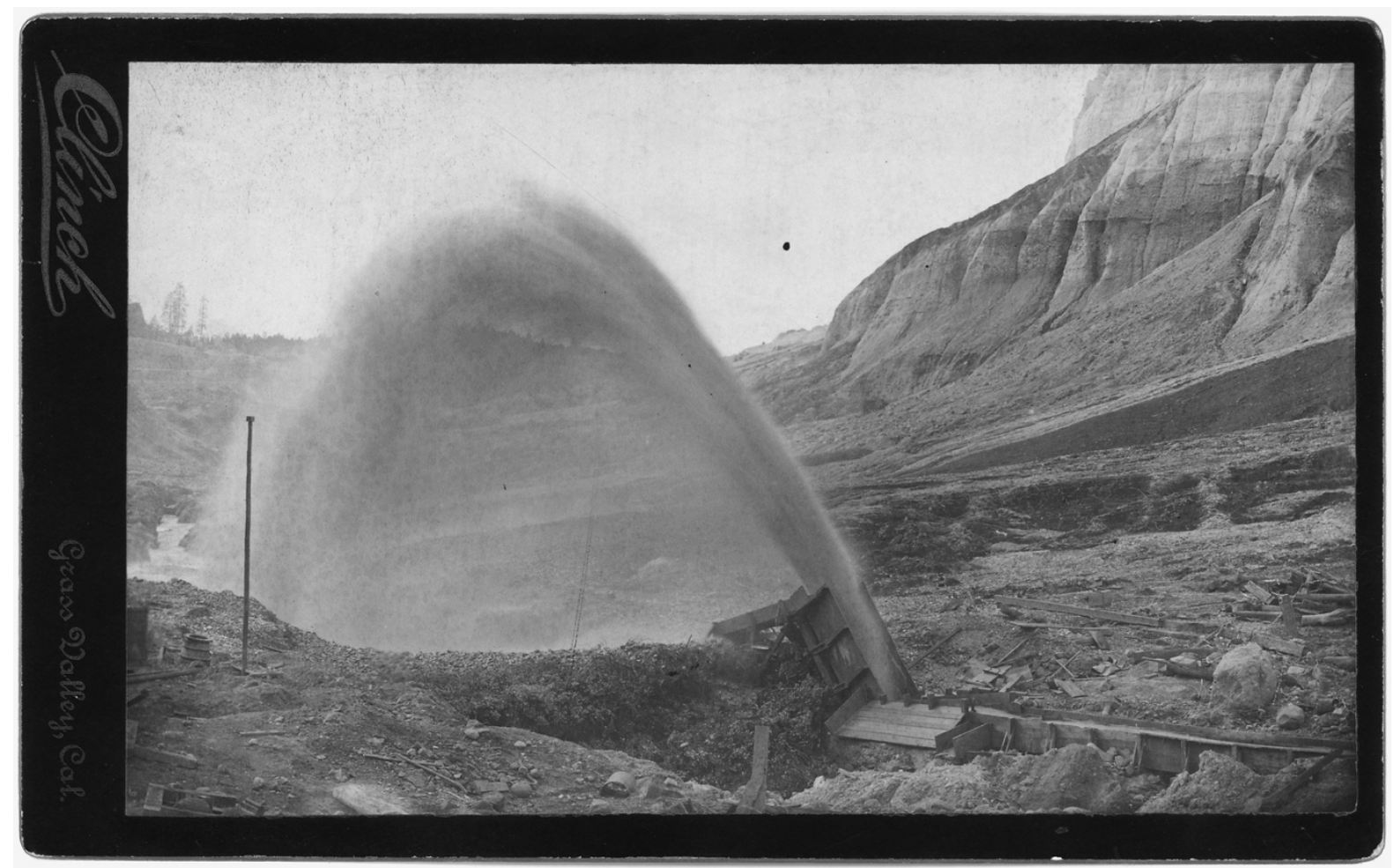

Figure 6. 'Clinch'. Respondent's Operating hydraulic mining elevator and impounding works at North Bloomfield Mine, entered as respondent's Exhibit 43, in the matter of Equity Case 7865, United States vs. North Bloomfield Gravel Mining Co. et al. US National Archives series: Civil and Appellate Case Files, compiled 1863 - 1911, NARA Identifier: 295959.

Recalling Mary Warner Marien's observation that it is difficult to think outside the terms of Watkins' imagery in order to fully comprehend the socioeconomic realities of mining, the 'Clinch' images comparatively perform this function 
by unmasking the means by which Watkins employs compositional techniques in order to create the illusion of mining as an activity which is congruent with the natural world. The importance of the 'Clinch' counter-aesthetic is that what could be described as the image's utilitarian and proto-reductivist qualities succeed in demythologising the spectacle of the 'industrial sublime' by depicting the Malakoff Diggins works as a tawdry and chaotic operation. As Terry Eagleton observes, the sublime is itself 'a thoroughly ideological category' (90) and 'Clinch' allows the audience an alternative appreciation of mining, which functions outside of a system of representation which is deeply rooted in the territorial and material acquisitiveness of capitalism. What we therefore find in 'Clinch' is evidence that in the aftermath of the Sawyer Verdict [1884] the technology of hydraulic mining continued to have an enduring environmental legacy upon the Sacramento Valley region.

If a comparison is made between the 'Clinch' photographs and Watkins' aesthetic of the 'industrial sublime', it becomes obvious that the compositional style of 'Clinch' represents a counter-aesthetic approach to Watkins' depiction of the same location. In his discussion concerning the contemporary photographer Edward Burtynsky - whose images of mines are in many respects analogous to Watkins' aesthetic of the sublime, - Joshua Schuster argues that the colossal vista required in order to create the effect of the 'industrial sublime' serves to place the viewer into a position of distant passivity (201), from which they can only view the mine as a spectacular spatial intrusion. Schuster's observation leads him to conclude that the 'industrial sublime' necessitates 'an uneasy relationship with forms of hands-on environmentalist activism' (194) because the aesthetic prevents the audience from developing a cogent sense of place. Schuster's observation is logical if we take into consideration that the 'industrial sublime' was intended by Watkins to signify the 
dominance of capital over the natural world. Whilst Schuster does not elaborate upon his understanding of what 'hands-on environmentalist activism' might entail, it is fair to say that in contemporary culture the role of an environmental activist would encompass a close encounter with polluted watercourses or soil deposits, in order to determine how the biological diversity of an ecosystem has been effected by the industrial transformations taking place in the locality.

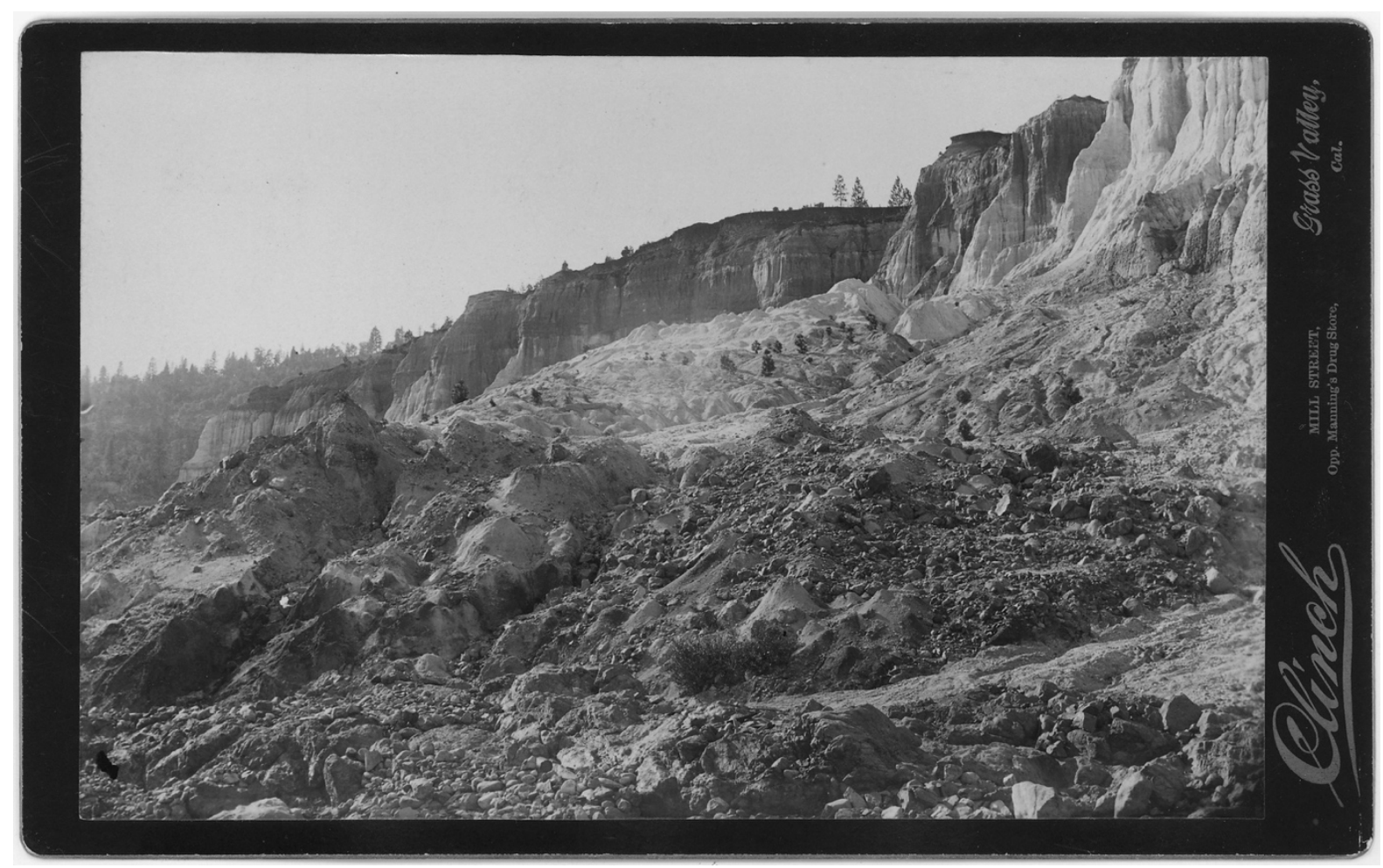

Figure 7. 'Clinch'. Respondent's Operating hydraulic mining elevator and impounding works at North Bloomfield Mine, entered as respondent's Exhibit 9, in the matter of Equity Case 7865, United States vs. North Bloomfield Gravel Mining Co. et al. US National Archives series: Civil and Appellate Case Files, compiled 1863 - 1911, NARA Identifier: 295956.

It is not the case that all of the 'Clinch' photographs are always strictly utilitarian in their aesthetic style of documentation. In 'Exhibit 9', figure seven, the photograph depicts the hydrauliced bedrock with compelling tonal detail. In this instance, the composition utilises a dark grey foreground of rocks at the bottom of the 
pit to lead the audience further into a middleground of tumbling rock and fissures, some of which increasingly appear chalky-white and sun-drenched, before the image climbs to the the stark cliffs of the mine face, which form a backdrop to the image. Interestingly, in this example by 'Clinch' the image depicts evidence of the arboreal forest, which can be seen in the hillside beyond the verge of the mine. The presence of the forest recalls how Watkins framed the flora in his Malakoff Diggins, Looking Northeast, near North Bloomfield, Nevada County (1871), Figure one. However, because the 'Clinch' photograph emphasises a close encounter with the mine floor, the remaining vestiges of the natural world on the horizon do not appear diminished by the spectacle of mining in the foreground, rather the trees appear to stand in ironic defiance against the prevailing chaos of the hydrauliced mine below.

According to the critic Rod Giblett, the 'industrial sublime' can be understood as 'a masking agent to hide the social and environmental realities of the sites' (93) photographed by consistently privileging sensations of awe over a commitment to informing the audience about the nascent ecological reality of a given location. Arguably the counter-aesthetic of 'Clinch' signifies the opposite; by enabling the audience to have a proximate encounter with the materiality of the mine, the viewer takes up the position of a 'hands-on environmental activist', which as Joshua Schuster argues is antithetical to the passivity that is typical of the aesthetic of the 'industrial sublime'. On one level this is an obvious enough observation - the signification of the image is dependent upon the intentionality of the artist - so Todd and 'Clinch' take up a position which is intended to show the despoliation of hydraulic mining, whilst Watkins' floating acquisitive gaze serves to flatter the industriousness of North Bloomfield's corporate shareholders. Nevertheless, the value of comparing Watkins against both Todd and 'Clinch' lies in the understanding that the counterpoising 
aesthetic strategies with which this trio of photographers documented the Malakoff Diggins pit, and beyond, were integral to the very first instances in which photography was utilised to promote corporate mining interests, or conversely campaign against them. This suggests that aesthetic modes of representation are historically rooted in pro- or anti-capitalist mining antipathies.

Unlike in Watkins' era, when the production of photography was almost exclusively situated in aesthetic codes rooted in commercial practice, as Marien suggests, the contemporary production of photographs depicting mineral extraction or environmental despoliation can be considered variously as Art; as activist imagery disseminated by NGO organisations, protest groups etc.; or conversely as documents which promote the interests of mining companies or corporations. Taking photography's present-day expansive role into account, it is important that contemporary artists and critics are aware of the historic origins and significations pertaining to the 'industrial sublime'. This is not to say that a series of photographs from a given location cannot include establishing and elevated viewpoints which convey something of the scale of large mining operations - the imposition of 'rules' in this regard would clearly be absurd. However, it is to suggest that the deployment of the 'industrial sublime' as the sole aesthetic strategy of representation could potentially be problematic if the image-maker's ethical aims and objectives lie in broad sympathy with an environmentalist credo.

In addition to debates concerning the composition of the photographs in this trio of photographers, the landmark legal cases concerning the North Bloomfield Co. are also socially valuable documents, which attest to the social upheaval caused by hydraulic mining and corporate mining interests in this period. In David Harvey's Seventeen Contradictions and the End of Capitalism, Harvey's sixteenth contradiction 
is entitled 'Capital's Relation to Nature'. Here Harvey expounds upon Marx's notion that capital and nature are two separate ontologies; instead Harvey asserts that: 'Capital is a working and evolving ecological system within both nature and capital are constantly being produced and reproduced' (247). As such, Harvey claims that capitalism creates 'its own distinctive ecosystem[s]' (251). Seen from the point of view of Harvey's analysis, the Malakoff Diggins pit represents a particular type of ecological transformation, which is emblematic of the emergence of the mining corporation as a social entity in the USA.

Certainly, the landscape of wheat farming which began to replace mining as California's primary industry in the aftermath of the Sawyer Verdict [1884] was not any less ecologically transformative than the mining industry, as native forest and grasslands became reconstituted as agricultural fields. Alan Trachtenberg observes that by the late nineteenth century farming was also becoming a corporate operation, as food production increasingly became geared towards the growing of 'cash crops', which were then packaged and transported to urban centres by large food conglomerates (21). Nevertheless, the residual landscapes created by hydraulic mining are direct expressions of the incorporated power of capital, and they reflect a profound alienation towards the natural world, which is unique to that industry. A complete disregard for flora and fauna, the need for huge reserves of water to be redirected for hydraulicing, and a profound indifference towards the welfare of adjacent communities such as the farmers which the Anti Debris Association represented, are characteristics which are all particular to California's corporate mining industry in this period. 
The denuded landscapes of the Malakoff Diggins pit, and the flooded fields in the Sacramento Valley below, are indicative of what Harvey terms as the 'virtual ecological transfer' (“Seventeen Contradictions” 256-7) of value. What Harvey is referring to is the phenomenon of uneven geographical development, in which localities proximate to mines typically exhibit '[...] exhausted soils, toxic waste dumps and devalued asset values' whilst 'the ecological benefits are located elsewhere' (ibid.) in the form of surplus value. This hubris is a direct result of a form of capitalist enterprise which had no geographical affinity with the locality of the mine and its environs, - after all shareholders hailed from urban centres or were investors from abroad. The court cases pertaining to the North Bloomfield Mining Co. therefore depict an early example of a conflict with what Harvey terms as 'extractive imperialism' (“Seventeen Contradictions" 258), which can be seen today in the actions of transnational mining companies, who exploit resources in developing countries in order to transfer the ecological benefits to developed nations. Indeed, it is no coincidence that after the Sawyer Verdict [1884] the bulk of mining operations relocated to remote territories where no existing environmental legislation was in place. As Harvey observes, capitalism's 'pollution problems do not get solved but moved around' (“Seventeen Contradictions” 259).

Although the Anti Debris Association had links to large-scale commercial farmers and prominent industrialists, who wanted to redirect the Californian economy in order to pursue their own self-interests, the legal campaign fought by the Anti Debris Association did also represent a broad swathe of landowners, who had a direct affiliation and dependence upon the agrarian sustainability of the region. Although the Anti Debris Association's fight cannot be easily characterised as a popular democratic movement of disenfranchised farmers, united against the common evil of corporate 
capitalism, the origins of today's environmentalist struggles against corporate interests are to be found in the landmark example of the Edward Woodruff vs. North Bloomfield [1884] trial. Photography, through the contributions of J.A. Todd and 'Clinch', played a modest yet important role in the struggle against corporate mining interests. Given that Carleton Watkins' pro-capitalist 'industrial sublime' is now regarded as eponymous to the history of California and the USA as a whole, it is significant that an alternate history of mining exists in which photography is employed as an activist tool, in order to hold corporate power and industrial polluters to account.

\section{Notes}

${ }^{1}$ Watkins' mammoth photographic plate is defined by Weston Naef as 'one made with a camera that exposes collodion negatives approximately $45.7 \times 55.9 \mathrm{~cm}(18 \times 22$ in.) in size, the majority of which date from 1861 to $1891^{\prime}$ (xx).

${ }^{2}$ The term 'industrial sublime' is coined by Edward Burtynsky in an interview with Craig Campbell (39-50). Importantly, Burtynsky does not expound upon the term to give a philosophical justification for it. However, further information clarifying Burtynsky's claim to the 'industrial sublime', wherein the artist cites influences such as the nineteenth century painter Philippe Jacques de Loutherbourg or photographers such as Carleton Watkins, can be found in Mark Haworth-Booth's 'Edward Burtynsky: Traditions and Affinities' (2003).

${ }^{3}$ Christine Hult-Lewis (40-1), describes how Watkins' photographs played an evidential role in legal land disputes, which helped to cement the photographer's reputation in the early part of his career. In particular, Hult-Lewis cites U.S. vs. Fossat 
[1857], which may have been the first use of a landscape photograph as evidence in juridical proceedings, this was followed U.S. vs. Castillero [1859], U.S. vs. Peralta [1865], and Lux vs. Haggin [1886].

${ }^{4}$ The host of water companies included 'the South Yuba Canal Company, the Excelsior, the California Water Company, the Eureka Lake and Yuba Canal Company. These and other companies built 5,276 miles of flumes, canals and ditches [in order] to supply water to the miners' (Project Underground).

${ }^{5}$ J.A Todd (b. England, 1827) is recorded as having a photographic gallery in Sacramento from 1877 - 1884. The son of an argonaut, Todd and his wife had moved to California in the 1850 s as part of the Gold Rush. Never successful at mining but adept at many skills, and with a longstanding interest in drawing landscapes, Todd drifted in to the commercial photography in Sacramento in the 1860 s because of the financial rewards the profession offered. Todd operated a number of photographic studios in Sacramento from 1868 until 1884, and exhibited widely throughout the region (Palmquist \& Kailbourn 549-551).

${ }^{6}$ With the exception of the two images presented in this paper, to the best of the author's knowledge Todd's other images remain unpublished and reside in the California Historical Society's library in San Francisco, USA.

${ }^{7}$ All of Todd's mounts have handwritten notes, which consist of the photograph's number from 1 to 17 (several are written as "Complainants Exhibit" numbers) and further court case descriptors. All mounts include the following (with slight variations): No. 2900 U.S. Circuit Court District of Cal., Edwards Woodruff vs. North Bloomfield Gravel Mining Co. et al. Most of the mounts contain handwritten captions describing the images, including locations (California Historical Society). 
${ }^{8}$ Between 1860 and 1879 four major expeditions sponsored by the U.S government surveyed, mapped, photographed and explored a large geographical region west of the Mississippi River.

\section{Works cited}

Auctivia Image Hosting. "W.A. Clinch image." Web. 10 November 2016. $<$ http://www.auctiva.com/hostedimages/showimage.aspx?gid=205113\&ppid=11 $22 \&$ image $=449877684 \&$ images $=449877684,449877704 \&$ formats $=0,0 \&$ format $=$ $0>$.

California Historical Society. "Photographs of the effects of hydraulic mining [graphic] / J.A. Todd." Web. 10 November 2016. $<$ https://beta.worldcat.org/archivegrid/collection/data/122569585>.

California State Parks. "Guide to the Malakoff Diggins State Historic Park Collection." Web. 10 November 2016. $<$ http://malakoffdigginsstatepark.org/history/north-bloomfield-gravel-miningcompany/>.

Campbell, C. "Residual Landscapes and the Everyday: An Interview with Edward Burtynsky." Space and culture: international journal of social spaces. 111 (2008): 39-50. Print.

Conford, D. "We all Live More Like Brutes than Humans. Labor and Capital in the Gold Rush." A Golden State, Mining and Economic Development in Gold Rush California. Eds. J. J. Rawls and R. J. Orsi. London: California UP, 1999. Print.

Cosgrove, D. E. Apollo's Eye: A Cartographic Genealogy of the Earth in the Western Imagination. Baltimore, Md; Johns Hopkins UP, London: 2003. Print.

Dasmann, R. "Environmental Changes before and After the Gold Rush." A Golden State, Mining and Economic Development in Gold Rush California. Eds. J. J. Rawls and R. J. Orsi, California UP, London: 1999. Print.

Eagleton, T. "The Ideology of the Aesthetic." The Discourse of the Sublime: Readings in History, Aesthetics and the Subject. Ed. Peter De Bolla. Oxford: Basil Blackwell, 1989. Print.

Giblett, R. J. Photography and Landscape. Bristol, UK: Intellect Books, 2012. Print.

Harvey, D. Seventeen Contradictions and the End of Capitalism. 1st ed. London, UK: Profile Books, 2014. Print.

Harvey, D. The Enigma of Capital and the Crises of Capitalism. London, UK: Profile Books, 2010. Print. 
Haworth-Booth, M. "Edward Burtynsky: Traditions and Affinities." Manufactured Landscapes. 4th ed. USA: Yale UP, 2005. Print.

Hoskins, G. People Like Us: Historical Geographies of Industrial-Environmental Crisis at Malakoff Diggins State Historic Park. 50 (October 2015). Print.

Hult-Lewis, C. "The Mining Photographs of Carleton Watkins, 1858-1891, and the Origins of Corporate Photography." Diss. Boston University, 2011. Print.

Isenberg, A. Mining California: An Ecological History. NY: Hill \& Wang, 2006. Print.

Jung, M. A. "Capitalism Comes to the Diggins. from Gold Rush Adventure to Corporate Enterprise." A Golden State, Mining and Economic Development in Gold Rush California. Eds. J. J. Rawls and R. J. Orsi. California UP, London, 1999. Print.

Kelley, R. Gold Vs. Grain. Glendale, CA: Arthur H. Clark Company, 1959. Print.

Knight, S. Federal Control of Hydraulic Mining. 7:9 (June 1898). Print.

Marien, M. W. "Imaging the Corporate Sublime." Carleton Watkins: Selected Texts and Bibliography. Ed. Amy Rule. 1st ed. Oxford: Clio Press, 1993. Print.

Naef, W. "Note to the Reader." Carleton Watkins: The Complete Mammoth Photographs. Eds. Christine Hult-Lewis, C.; Weston Naef. Los Angeles: J. Paul Getty Museum, 2011. xx. Print.

Palmquist, P.; Kailbourn, T. Ed. Pioneer Photographers of the Far West: A Biographical Dictionary. Stanford CA, Stanford UP, 2000. Print.

Pisani, D. "I Am Resolved Not to Interfere but Permit all to Work Freely. The Gold Rush and American Resource Law." A Golden State, Mining and Economic Development in Gold Rush California. Eds. J. J. Rawls and R. J. Orsi. California UP, London, 1999. Print.

Project Underground. "Legacy of Poison." www.1849.org. Ed. P. Chatterjee. Web. 10 November 2016. <http://www.1849.org/ggg/legacy.html>.

Schuster, J. "Manufacturing and Landscapes: Edward Burtynsky and the Photography of Ecology." Photography and Culture 6.2 (2013): 193-212. Print.

Trachtenberg, A. the Incorporation of America, Culture \& Society in the Gilded Age. New York: Hill \& Wang, 1995. Print.

NARA, US National Archives Online Public Access. " Civil and Appellate Case Files, 1863 - 1911, US vs. North Bloomfield Mining Company, 1897-1899." 2014. Web. 10 November 2016.

$<$ https://commons.wikimedia.org/wiki/Category:North Bloomfield Mining and Gravel Company>. 